\title{
Department of Biochemistry, Molecular Biology and Nutrition: Dynamic and Innovative
}

\author{
$\$$ \\ Noel Martin S. Bautista, MD, MBA \\ Bien J. Matawaran, $M D^{\prime}$ \\ Mary Jocelyn Yu-Laygo, MD'
}

Biochemistry is both life science and chemical science since it explores the chemistry of living organisms and the molecular basis for changes occurring in living cells. Consistent with its definition, the department has been a source of dynamic changes in teaching methods for the UST-FMS. The Department of Biochemistry, Molecular Biology, and Nutrition have a yearly subject that aims to provide students with a comprehensive working knowledge of basic biochemistry including molecular biology and basic nutrition. This knowledge will help facilitate their understanding of the molecular basis of diseases and subsequently enable them to relate biochemistry to future clinical subjects in the medical curriculum.

The didactic portion in biochemistry is divided into different blocks based on the different systems of the body and integrated with other disciplines like Physiology, Anatomy, Neuro-Anatomy, and Histology.

Problem sets, case discussions, and journal researches in relation to the case discussions are regularly assigned to enhance student learning. Additionally, laboratory experiments are conducted to augment the didactic concepts learned and encourage research activities.

Mary Jocelyn Laygo

miyulaygo@yahoo.com

Department of Biochemistry, Molecular Biology \& Nutrition, Faculty of Medicine and Surgery, University of Santo Tomas
This time tested and highly regarded system has been acknowledged to be effective by the students for several years but the department has been continually innovating to make learning for students and faculty members easier and enjoyable.

\section{WHAT ARE THE CURRENT INNOVATIONS?}

\section{Online Laboratory}

The department has started encouraging students to vicariously perform some experiments via the Internet, sort of an online laboratory. There are experiments online that can augment actual experiments performed by the students. The links to such online experiments are given to the students before or after an experiment for them to try their hands on doing the experiments in their own places at their own time. Such experiments include agarose gel electrophoresis and Enzyme-Linked Immunosorbent Assay (ELISA) tests.

\section{SELF-INSTRUCTIONAL MODULE (SIM)}

Self-Instructional Module (SIM) is an alternative activity to overcome challenges caused by unscheduled class suspensions. As the term implies, the students are given the responsibility of learning the material on their own. The students are given the material with entry and terminal competencies. Pre-test questions are answered before reading the SIM to assess their 
initial knowledge and review questions after each topic. They are then tasked to submit the answers to questions at the end of the module to their respective facilitators. This will constitute a recitation grade in lieu of a small group discussion (SGD) session. The answers are posted on the department's bulletin board or UST Cloud Campus for their information.

\section{E-BASED COMMUNICATIONS}

The department is well commended for its extensive use of the Internet or e-based communications. This is especially useful for immediate announcements that are time-sensitive, like changes in schedules due to weather disturbances. These communications are facilitated via the university's cloud campus/blackboard facility and the department's Facebook page (http://facebook.com/ustmedbiochem). Some information is also posted via these tools like examination dates and topic coverage (item breakdown), clarifications on grades, special activities, for eg, journal report, nutrition festival, etc. Even small group discussions are done either via Google classroom or the UST Cloud Campus by some facilitators.

\section{ONLINE SURVEYS VIA GOOGLE}

In order to gather feedback on teacher competence and effectiveness, the department regularly encourages students to answer online surveys. The feedbacks are then collated and confidentially forwarded to the staff concerned. During department meetings, comments regarding the department and suggestions submitted by the students are discussed for corrective action/preventive action (CAPA).

\section{EXAMINATION QUERY FORM}

After each written examination, the answer keys are posted on the bulletin board. If there are questions to the answers posted, the students are encouraged to contest such by filling-up an Examination Query Form within 24 hours after a quiz or 48 hours after a departmental/shifting examination. Once received, the concerned lecturer who made the question and the answer are required to respond to the query form submitted. Resolution of the queries submitted is posted in the department's bulletin board so that the students learn from the answer in question. In this way, any issues, challenges or clarifications regarding examination answer keys and their resolution will be well-documented.

\section{MID-YEAR REMEDIALS}

The department gives out mid-year remedial examinations to students with failing grades in the first two shiftings. Students with grades (average of the first and second shifting grades) below 74.5 are qualified to make the mid-year remedials. The average of the $1 \mathrm{st}, 2 \mathrm{nd}$, and remedial exams are taken and if this is higher than the average of the first and second shifts, this new average will be their grade for their first and second shiftings but will be capped to a maximum of 74.5 .

However, the mid-year remedials will only be implemented if there would be 20 or more (>20\%) percent of the total number of students who would be failing the subject for the first two shiftings.

\section{THE USE OF ZIPGRADE IN CHECKING QUIZZES}

The Zipgrade system is an electronic-based checker via a smartphone or tablet that acts as an optical grading machine similar to a scantron. It is an easier, faster, and accurate means of checking students' quizzes. Prior to its implementation, the staff would manually check short quizzes of around 25 to 30 items allotting about 60 test papers per staff member. This was noted to be time-consuming, tedious, and sometimes prone to human error. The zip grade format was proven to be faster and more convenient and the digital image was recorded and saved, thus tamper-proof as well.

\section{OTHER INNOVATIVE TEACHING STRATEGIES}

The department is also implementing some innovative teaching strategies like the Biochemistry Journal Report, which aims to establish a link between research and the health sciences with its emphasis on promoting the importance of biochemistry in medicine. This activity is usually done after the semestral/ Christmas break to afford the students ample time to prepare. This comprises 10\% of the students' second shifting grade.

Another innovative teaching strategy is the annual Nutrition Festival. This is scheduled during the fourth shifting period with a specific theme for every 
academic year. This is to empower the students to apply the basic principles of nutrition in the actual preparation of meals and at the same time allowing them to showcase their talents in the performing arts. The students are given guidelines and criteria for judging. The department invites nutritionists from the University of Santo Tomas Hospital to be part of the judging panel to evaluate the meals prepared by the students to see if these conform to the truthfulness to nutrition concepts. The nutrition festival grade is $10 \%$ of their fifth shift (final examinations).

Internet-based learning tools like "Plickers" are also utilized by the staff to initiate interactive and fun sessions with the students during SGD.

The department is unceasingly met with challenges in its pursuit of competent and effective teaching of biochemistry to future doctors. As such, it is always on the lookout to overcome these challenges.
It is a dynamic department that always strives to improve on current practices and aims to bring out the best in both the mentors and the students alike.

Open Access This article is licensed under a
Creative Commons Attribution 4.0 International
License, which permits use, sharing, adaptation, distribution
and reproduction in any medium or format, as long as you give
appropriate credit to the original author(s) and the source, pro-
vide a link to the Creative Commons license, and indicate if
changes were made. The images or other third party material in
this article are included in the article's Creative Commons li-
cense, unless indicated otherwise in a credit line to the material.
If material is not included in the article's Creative Commons li-
cense and your intended use is not permitted by statutory regu-
lation or exceeds the permitted use, you will need to obtain
permission directly from the copyright holder. To view a copy of
this license, visit http://creativecommons.org/licenses/
by/4.0/.

(c) (i) Open Access This article is licensed under a License, which permits use, sharing, adaptation, distribution and reproduction in any medium or format, as long as you give appropriate credit to the original author(s) and the source, provide a link to the Creative Commons license, and indicate if changes were made. The images or other third party material in this article are included in the article's Creative Commons license, unless indicated otherwise in a credit line to the material. If material is not included in the article's Creative Commons license and your intended use is not permitted by statutory regu orceds the permitted use, you will need to obtain by/4.0/. 